"This is an Author's Original Manuscript of an article whose final and definitive form, the Version of Record, has been published in South European Society and Politics (4 Mar 2008) [copyright Taylor \& Francis], available online at: http://www.tandfonline.com/

[DOI : http://dx.doi.org/10.1080/13608740902738384]." 


\title{
PARTY POLITICAL REPRESENTATION IN PORTUGAL
} Ana Maria Belchior

\begin{abstract}
This study analyses the degree to which Portuguese parties represent their electorates. In this instance, representation is measured by the degree of congruence between those who vote and those who are elected. The analysis has two dimensions: ideological positioning and attitudes towards democracy. On the first dimension, it appears that, compared to the voters, the parliamentary elite is ideologically more extreme. On the second dimension, we find elites are more favourable towards democracy than the electorates they represent.
\end{abstract}

Keywords: Portugal, political parties, democracy, political representation, political congruence

Notwithstanding the vast academic literature on political representation, the complexity and breadth of the subject justify research into some relatively unexplored aspects of the topic. Among these is the study of the quality of representation provided by political parties (Dalton 1985, pp. 271; Etzioni-Halevy 1993, pp.13-14). The focus of the present article is representation, measured as the congruence between Portuguese political parties and their voters. Such research is important for several reasons. Firstly, Portugal is very rarely included in comparative or international studies in this field. Indeed, we have no knowledge of significant research on Portuguese parties' representation. Secondly, there is evidence of increasing disaffection and even divorce between parties' representatives and voters in Portugal (Magalhães 2004).

Our analysis focuses on those political parties currently represented in the Portuguese Parliament. ${ }^{1}$ The Socialist Party (PS - Partido Socialista), established in 1973, and the Social Democratic Party (PSD - Partido Social Democrata), founded in 1974, are the largest Portuguese parties. They are commonly considered closest to catch-all parties and have alternated in government since 1975, following the 1974 the Carnation Revolution which changed the Portuguese regime from dictatorship to democracy. Despite its title, the PSD is positioned on the centre-right of the political 
spectrum and participates in the EPP-ED group of conservatives and Christian Democrats in the European Parliament. To the right of the PSD is the Democratic Social Centre/People's Party (CDS/PP - Partido do Centro Democrático e Social/Partido Popular), the party furthest to the right in the Portuguese parliament. Closest to the cadre party type, it was formed in 1974 and represents conservative voters. The communist Party (PCP - Partido Comunista Português) is, as its name implies, a Marxist-Leninist party. Founded in 1921, it is the oldest Portuguese party. The fourth main party, it is also the only one that can properly be considered a mass-based party. The Portuguese Greens were founded in 1982 and have formed a coalition with the PCP since 1991. As the Greens do not present themselves as significantly different from the PCP in political or programmatic stances (see e.g. Belchior 2007, sub-Chap. 3.3), for analytical purposes the coalition of these two parties, Unitarian Democratic Coalition (CDU - Coligação Democrática Unitária), is considered as synonymous with the communist section of the political spectrum. Finally, Left Block (BE - Bloco de Esquerda), founded in 1998, is a new left party. BE's electorate is considered the closest to the post-materialist voters' profile and, therefore, to the left libertarian parties (Belchior 2007, sub-Chap. 3.3).

No research has yet been conducted on political representation using measures of congruence in Portugal or indeed in other South European countries. A comparative analysis is, therefore, necessarily limited by such lack of data and studies. Hence, this article aims to contribute by beginning to fill this lacuna. The article starts with a short overview and discussion on the theory underlying the concept of representation. This is followed by a presentation of the methodology (the measures of representation to be used, the hypothesis and data sources). Finally, the empirical findings are presented and discussed.

\section{Defining Representation}

According to some authors, the delegate model - the style of representation in which the views of electors and their interests determine the political behaviour of their representatives - represents an obsolete vision of representative democracy (Birch 1971, p. 100; Eulau 1987, p. 212; Thomassen 1994, pp. 240-243 and p. 249). It is argued that the delegate style of representation, despite being perfectly reasonable as a set of recommendations for parliamentary behaviour, is misleading if taken as a model for actual practice (Birch 1971, p. 100). Indeed, insofar as representative government is 
based on the idea that parliamentarians are granted leeway to make decisions independent of their voters' views, then the delegate model cannot be applied to the modern idea of representative democracy (Manin 1995, Chapter 5). That model should, therefore, be seen as utopian and perhaps even counter-productive, as it may potentially work against democratic interests themselves.

The conception of a representative, as opposed to a delegate model of democracy, can be traced back to a famous speech made by Edmund Burke in 1774. He declared that models of representation based on the judgment and reflection of the representatives are those most compatible with modern democratic states (quoted in Birch 1971, pp. 78-79). The Federalist Papers also point out that 'it may well happen that the public voice, spoken by the representatives of the people, will be more consonant to the public good, than if spoken by the people themselves' (Madison 2001 [1787], p. 46). Thus, the basis of the rejection of the delegate model lies, especially, in the supposed difficulties inherent in the implementation of a mandate model of democracy, as well as in perceptions of citizens' lack of competence concerning political action.

More recently, Hanna Pitkin agreed that 'representing (...) means acting in the interests of the represented, in a way that corresponds to them', although she reconciles this view with the premise that the representative's action is independent of the represented (1967, p. 209). This means that representation binds representatives to congruence with the public, although it does not rule out political decisions which may diverge from the electorate's views if the public interest appears to lie elsewhere (Pitkin 1967, p. 213, pp. 221-224; Jacobs and Shapiro 2000, pp. 303-306).

Despite this debate, it is normatively assumed that representatives should serve the interests of those they represent. Even if it is agreed that the delegate model of democracy presupposes an understanding of representation that may contradict democratic values, this model does appear to bring voters closer to the centre of political power. This is an even more attractive perspective if we take into account both citizens' growing sophistication and manifest dissatisfaction with politics in modern democracies. Although the model should not be understood as the only legitimate vision of democratic representation (Eulau \& Karps 1977; Jewell 1983; Thomassen 1994, p. 238 , pp. 257-258), it does seem to offer a viable and relevant framework for studying the topic. Thus, in this article representation is measured in terms of the congruence which exists between the electorate and their representatives. This perspective goes 
back to the seminal work of Miller and Stokes (1963), later developed by others (Barnes 1977; Converse \& Pierce 1986; Miller et al. 1999). ${ }^{2}$

As fundamental actors in the democratic process, political parties are the key formal channel connecting the will of the people to its representation in parliament. As such, parties are considered intermediaries in the political process (Putnam 1976, pp. 154-155; Barnes 1977; Dalton 1985). Furthermore, the electoral connection provides a basis for assessing the congruence between citizens and elites (Dalton 1985, p. 278; Powell 2000, p. 5). In fact, the general goal of political parties, inherent in the function of representation, is to generate a reasonable degree of affinity and ideological proximity with their electorates, in order for citizens to develop identification or at least a degree of closeness to a given party. This article will attempt to measure the extent to which Portuguese political parties respond to this objective.

The existing empirical research on the subject of political representation in Europe includes the study by Converse and Pierce (1986) on political representation in France using data collected in the mid-1960s; the research by Barnes (1977) on representation in Italy in the 1970s; the study by Dalton (1985) of European Parliament candidates and European publics, using comparative data fielded in 1979; the analysis by Esaiasson and Holmberg (1996) of political representation in the Swedish Parliament; and the work by Miller et al. (1999) which analysed not only the European countries considered in the preceding research, but also Germany, the Netherlands, and the USA. ${ }^{3}$

These studies form the departure point for our hypotheses. However, given the diversity of methodologies which they employed, the different issues which are studied and the diverse approaches undertaken, it is not possible to define a specific frame of analysis or a singular pattern of representation. Our options are closest to those followed in Russell Dalton's work, which was a specific reference point throughout our analysis.

\section{Methodology}

It is no simple matter to define political representation and to identify a set of criteria that allow the concept to be measured empirically (Birch 1971, p. 124; Esaiasson \& Holmberg 1996, p. 83; Przeworski et al. 1999). On the delegate model assumption that greater indices of similarity correspond to greater representation, measurement of the concept has often rested on the association or correlation between the mean positions of 
the party elite (or political parties' programmes) on political matters, and the mean position of their voters.

There are, however, certain methodological difficulties inherent in this vision, concerning the measurement's accuracy, the meaning of mean values, and the magnitude of standard deviations for the two actors' positions. These problems mean that often the highest values of association do not necessarily mean greater proximity between elites and their respective electorates (Pierce 1999, pp. 13-15). The presentation of mean values is, nevertheless, valuable due to their simple and intuitive nature. They will therefore be included in this analysis, since their drawbacks will be reduced by the complementary nature of other measures.

In a seminal study of representation, Achen (1978) devised forms of statistical measurement of different dimensions of the concept namely, proximity, centrism, and responsiveness. These will be used in the present study to complement the correlation measures. Proximity measures the similarity of the party's position to that of its voters (Achen 1978, pp. 483-484). That is:

$$
\hat{\mathrm{S} j}=\sum(\mathrm{aij}-\mathrm{rj})^{2} / \mathrm{nj}
$$

where $a i j$ is the position of voter $a i$ in party $j, r j$ the mean position of the elite in that party, and $n j$ the size of the sample.

Centrism captures the differences between electors and the votes they represent, measured as the mean or median voter. Centrism is measured by the difference between proximity and the variance with regard to the position of the electorate (Achen 1978, pp. 487-488). Thus,

$$
\hat{\mathrm{Y}} \mathbf{j}^{2}=\sum(\mathrm{aij}-\overline{\mathrm{a}} \mathrm{j})^{2} /(\mathrm{nj}-1)
$$

measures the variance for the electorate, where $\bar{a} j$ is the median position of the voters; ${ }^{4}$ and

$$
\hat{C} j=\hat{S} j-\hat{Y} j^{2}
$$

is the measure of the centrism in party $j$. High proximity or centrism values indicate a mismatch between voters and elites. Low values indicate the reverse. 
The third measure used is Responsiveness, which not only assumes that elites should have similar opinions to their supporters, especially on the substantive content of political choices (Birch 1971, p. 107), but also defines this in relational terms, by measuring the correspondence between the voters' opinions and those of the elite. This measure consists of a simple linear regression equation in the following terms:

$$
r=a+b \cdot x i+e
$$

where $r$ is the expected position of the representatives, $x i$ is the electorate's position, $a$ is the expected position of the representative when the electorate's position is zero, $b$ corresponds to the expected change in the representative's position when the electorate's position changes a unit, and $e$ is the error term. Where $b$ is larger than unity, representatives are more polarised on the issue concerned than the voters they represent. On the contrary, if $b$ is smaller than one, then the party representatives' positions do not reflect the ideological polarisation of their voters. In other words, party representatives are more centrist than their voters: they are sub-responsive to them. Responsiveness exists when the position of the voters predicts similar positions by the representatives, i.e. when $b$ equals unity.

Responsiveness can also be measured by Pearson's correlation coefficient. ${ }^{5}$ Indeed, in addition to the measures of representation presented above, a simple correlation can assess the difference between the mean positioning of the party elite and that of its electorate, if divided by the standard deviation of the position of the latter. This latter measure represents the deviation in the elite's position from the electorate's mean position in standard deviation units. This measure, termed the Standardised Deviation, has the following formula:

$$
\mathrm{Zj}=(\mathrm{rj}-\mathrm{aj}) / \mathrm{sdj}
$$

where $r j$ is the mean position of the party elite, $a j$ the mean position of the voters, and $s d j$ the standard deviation of the voters for this party. In this measure, too, high deviation values indicate a lack of coincidence between the voters and the elected. Low values indicate the reverse. ${ }^{6}$

Therefore, the study of representation from the perspective of congruence between MPs and voters within each of the Portuguese political parties is based on the 
application of the following measures: means and their deviations and differences; proximity, centrism, responsiveness, and standardised deviation.

The present study is structured around the response to two main hypotheses. The first hypothesis is derived from previous studies which have shown that, both on the left and on the right, the political elite tends to be ideologically more extreme than voters (see e.g. Barnes 1977; Dalton 1985, p. 275; Converse \& Pierce 1986, p. 128; Esaiasson \& Holmberg 1996, pp. 92-95; Thomassen 1999, p. 46-50). This difference is generally due to the positioning of the political elite further to the left than voters (Dalton 1985, pp. 283-284; Thomassen 1994, p. 255; Thomassen, 1999, pp. 50-53; Thomassen \& Schmitt 1999, p.191, pp. 198-199). Nonetheless, it has been shown that communist parties are a partial exception to this trend since they tend to exhibit higher levels of congruence with the electorate they represent (Klingemann 1995, pp. 197-198). Our first hypothesis, therefore, assumes that the elite are ideologically more extreme than the voters they represent, especially on the left, with the exception of the communist parties, where greater congruence may be expected.

Secondly, there is a widely-supported assumption that the political elite displays a higher commitment to democratic values and procedures (e.g. Putnam 1976, p. 116; Etzioni-Halevy 1993, p. 110; Dye \& Zeigler 2006, p. 17). Our second hypothesis, therefore, is that the elite is more supportive of democracy than voters.

Both hypotheses serve to provide a comparative assessment of the levels of congruence produced by the Portuguese political parties. The two dimensions of analysis - ideological position and attitudes towards democracy - will be examined, firstly, by measuring the mean positions of the elected and the voters and, secondly, by gauging the other measures of congruence.

The analysis uses empirical data drawn from two recent surveys. The first, a study conducted in July 2006 under the Participation and Democratic Deliberation project at ISCTE, ${ }^{7}$ polled 1,001 Portuguese voters. The second, entitled A Study of Portuguese MPs, is an elite survey of 79 Portuguese Members of Parliament, conducted by the author in the first three months of $2007 .^{8}$

\section{Degree of Congruence in Ideological Positions}

Certain recent studies report the existence of a crisis in the representation of electorates (Porras Nadales 1996), whereas others argue that political parties are good 
representatives of public preferences (Dalton 1985, pp. 293-294; Klingemann 1995, p. 195). Generally speaking, low indices of congruence have been detected between voters and parties (Thomassen 1994; Miller et al. 1999; Pierce 1999). However, the extent of congruence seems to vary with the issue used to measure it. Congruence is higher for socio-economic issues, such as labour policy, as well as for moral issues. It is lower for external policy matters and seemingly non-existent for topics such as aid to the Third World or law and order (Thomassen 1994, p. 255; Thomassen \& Schmitt, 1999, p. 199). But these trends are neither stable nor susceptible to generalisation, and may involve other nuances (Dalton 1985, pp. 380-381; Thomassen 1999, pp. 45-52).

At an ideological level, congruence appears to be more significant, particularly with regard to positions on a left-right scale as well as for issues which are perceived as highly ideological (Dalton 1985, p. 283; Thomassen 1994, pp. 254-256; Pierce 1999; Thomassen 1999, p. 53). Accordingly, we expect congruence to be higher when considering issues that pertain to ideological identities or when the issues have been intensely politicised. Congruence should decline as we move towards questions that are less politicised or generate little political dispute.

As in other work in the same area (Esaiasson \& Holmberg 1996; Schmitt \& Thomassen 1999), in order to measure ideological congruence we opted first of all for a comparative study of the mean positions that the parliamentary elite and their voters assigned themselves on a left-wing/right-wing scale. For the MPs, the question was as follows: 'Generally speaking, using a scale from $0-10$, where 0 means "furthest to the left" and 10 means "furthest to the right", how would you position yourself on this scale?' Similarly, for the voters, the question was: 'With regard to political matters, people regularly talk about the left and the right. Generally speaking, using a scale from 0-10, where 0 means "furthest to the left" and 10 means "furthest to the right", how would you position yourself on this scale?' Next, voters' party position was assessed by the question: 'Did you vote in the last legislative election (2005)? If so, which party did you vote for?' Graph 1 shows the results.

[Graph 1. left-right mean self-positioning - ABOUT HERE]

As predicted, and in line with the results obtained in other research (McClosky et al. 1960; Barnes 1977; Dalton 1985, p. 275; Converse \& Pierce 1986, p. 128; Esaiasson \& Holmberg 1996, pp. 92-95; Thomassen 1999, pp.46-50; Thomassen \& 
Schmitt 1999, pp. 199-200), it can be seen that, on both left and right, MPs locate themselves at a more extreme position on the left-right scale than their electorate. The only exception concerns the centre-right PSD electorate, which is clearly to the right of its MPs. In general terms, the graph shows less ideological commitment on the part of the electorate, which places itself in median positions on the scale. This finding may be partly explained by voters' less developed political sophistication in comparison to the elite. This is particularly conspicuous in the small political parties, whose political style betrays a strong ideological commitment by the elite, in keeping with the theory (Panebianco 1990, pp. 347-348), and whose position is, therefore, more distant from the centrist tendency of the electorates. Table 1 presents detailed information on this relationship.

[Table 1. left-right mean self-positioning - ABOUT HERE]

In effect, for all the parties except the right-wing CDS/PP, the calculation of the differences between the mean positions of MPs and voters shows an asymmetry tending towards the left, which is visible in the negative values for the differences. This validates the assumption of a more left-wing position by the parliamentary elite in relation to its electorate, and corroborates the results obtained elsewhere (Dalton 1985, pp. 283-284; Thomassen 1994, p. 255; Thomassen 1999, pp. 50-53; Thomassen \& Schmitt 1999, p. 191, pp. 198-199).

Our first hypothesis also proposed that the communist party would constitute an exception to this trend. However, Table 1 categorically challenges this assumption. Against our expectations, the communist CDU is, of all parties, the one that reveals the greatest difference in mean positions between voters and their elite. It is conceivable that this divergence can be explained by the PCP's persistence in aligning itself ideologically with more orthodox communist positions, whereas its electorate has shifted to a less extreme position, in line with what has happened with the electorates of the other Portuguese parties.

Further analysis carried out elsewhere (Belchior 2007, pp. 315-316) shows that in other European party systems, communist parties are not the most congruent parties, but quite the reverse. Indeed using similar measures of congruence to the ones employed above, a substantial number of communist parties were found among the group of the least congruent in the old fifteen EU member states. For instance, in Spain 
the communist party Izquierda Unida was found to be the least congruent party in the Spanish party system.

At the centre, the socialist PS records the least difference in positions and, therefore, the greatest mean congruence between the elected and the electorate. It is also worth pointing out that of all the parties, the PS exhibits the greatest standard deviations associated with the positioning of the voters. ${ }^{9}$ This confirms that the party's electorate is less cohesive than the parliamentary elite.

In summary, our first hypothesis concerning the asymmetry of ideological positions between voters and the elected, with the latter locating themselves at more extreme positions than the former, especially on the left, is generally confirmed in these findings from Portugal. The communists, however, do not enjoy greater ideological congruence, as we had initially posited.

[Table 2. Measures of representation for left-right self-positioning - ABOUT HERE]

Next, we present the four measures of representation presented above, using leftright positioning of those surveyed (see Table 2 above). In terms of the absolute similarity between voters and the elected, a first reading suggests that the latter are not good ideological representatives of the former. In particular, the results of the communist $\mathrm{CDU}$, followed by the new left $\mathrm{BE}$ and socialist PSD, indicate that voters seem to differ substantially from the ideological positions of their parties. The PS emerges as the party with the lowest result in the proximity measurement, signifying that its MPs have the closest ideological position to their electorate.

We turn now to the level of variation in the positions of each party's voters, namely centrism. Using this indicator, the previous findings are largely maintained, though at significantly lower levels which, therefore, indicate greater representation of the median voter in each party. Using this measure, the CDS/PP emerges as the party with the greatest ideological representation of its voters, given the negligible difference between the party's position and the median positioning of the voters.

The standardised deviation not only confirms the effective position of the Portuguese party elites to the left of their electorate (and the exception of the CDS/PP), but also bears witness to the greater representation of the PS and CDS/PP electorates and the lower representation of that of the CDU. The regression coefficient has a higher value than unity, confirming that the ideological representation of the Portuguese 
political parties is more extreme than that of the electorates. Finally, the correlation coefficient indicates that, as a whole, the parties represent the electorates' ideology, given the magnitude of the correlations and the fact that for each party the sign is positive. This suggests that the difference in ideological positions among the different party electorates is broadly reflected in the parties.

These results allow us to state that, despite the small discrepancies noted, Portuguese parties generally appear to correspond to the ideological differences among their electorates, although with the MPs holding a more pronounced ideological position. Accordingly, the first hypothesis is validated.

Moreover, our findings for Portugal match a similar study carried out for the fifteen member-states (Belchior 2007, pp. 307-310). Considering these democracies, and using similar samples of MPs and voters, a statistically significant linear relationship was found with respect to left-right self-placement (it varies between $\mathrm{R}^{2}=0,84$ and 0,99; Portugal being in a median position, as well as Spain with $\mathrm{R}^{2}=0,92$, while Italy is at the lower level with $\left.\mathrm{R}^{2}=0,84\right)$. Second, this positioning is slightly biased in approaching the extremes, i.e. MPs were found to be further to the right and to the left than their voters, as was the case in Portugal. Finally, this bias is stronger on the left of the ideological spectrum.

\section{Perceptions in Relation to Ideological Positioning}

The way politicians act often depends on their perceptions of the voters' position. Voters, too, frequently define political preferences in accordance with their perceptions of political parties and leaders. So it is important to investigate ideological representation a little further, this time through the prism of perceptions of ideological positions. Various authors have reflected on and analysed the question of how important and concise these perceptions are (e.g. Clausen et al. 1983; Converse \& Pierce 1986, p. 221; Thomassen 1999, pp. 35-36; Van der Brug \& Van der Eijk 1999).

The dynamics of voters' opinions and attitudes are regularly restricted by the arguably distorted perception that their parties or candidates share their positions. Their view may underestimate some real differences of position between the two. Politicians also tend to believe that their voters have the same perspective as they do (Converse \& Pierce 1986, Chap. 9; Esaiasson \& Holmberg 1996, pp. 116-117; Holmberg 1999). This can result in a perceptual error between the voters' ideological position and that of the 
elites. Thus, the parliamentary elites perceive greater convergence between their own positions and those of their electorates than is actually the case. Similarly, it is expected that voters are unable to assign an accurate ideological position to their political parties, resulting in a discrepancy between voters' perceptions and the positions attributed to them by the elite.

Three variables were used for these measurements: the MPs' ideological selfpositioning, their perception of their voters' ideological positioning, and their perception of their political parties' ideological positions. The MPs' perception of the voters' position was measured on the basis of the question: 'On a scale of $0-10$, where 0 means "furthest to the left" and 10 "furthest to the right", where do you think the mean position of your party's electorate is located?' And for the MPs' perception of the political parties' positions, the question was: 'At what point on this scale (on which 0 signifies "furthest to the left" and 10 "furthest to the right") would you locate your party, or what number on the scale would you give it?'

For the five Portuguese political parties, a picture of almost perfect congruence between the MPs' mean position and their perceptions of their political parties' and voters' positions emerges (Table 3). Although perceived congruence between MPs and the parties they represent is to be expected, ${ }^{10}$ the perceived congruence between MPs and electors needs to be discussed. The electorates' own positions on the left-right scale, as presented above, and the MPs' perceptions of these are relatively divergent. The MPs believe that their own and their electorates' ideological positions overlap, which, as observed in the section above, does not reflect reality. In fact, for all parties, the ideological positions occupied by the representatives and the represented do not coincide.

[Table 3. MP's left-right self-positioning and mean perceptions of their voters' and political parties' positions - ABOUT HERE]

These differences between MPs' positions and their perceptions of their voters' and parties' positions shows (though only very weakly) that MPs perceive both their party and their electorate as positioned to the right of their own positions. With the exception of the CDS/PP, whose electorate is really to the left of its MPs, these perceptions reflect the reality as shown in the previous section, even though the 
differences are much smaller when measuring them through MPs' perceptions of voters' positions.

Generally speaking, the results suggest that, from an ideological perspective, the elite presupposes that a near-congruence exists. Our findings reveal that it does not. This can have consequences for political activity if the sense of a strong ideological representation reduces the will of the elite to seek greater closeness to the voters. This same misperception by MPs has been found in all fifteen EU member-states (Belchior 2007, pp. 310-311).

One of the reasons that may be cited for the above discrepancy is connected with the reported heterogeneity of the voters' positions, which, as we have seen in Table 1 , is quite large in all political parties. This heterogeneity seems to be associated with a higher probability that errors of perception occur in the elite with regard to those positions (Clausen et al. 1983), and may be at the root of the discrepancy observed.

At an ideological level, it is also hypothesised that the electorate cannot accurately identify the position of the political party it voted for, thus leading to a marked discrepancy between the electorate's perception and the party's position as indicated by its elite. The voters' perception of the parties' ideological position was measured by the following question: 'Consider a scale of 0 to 10 , in which 0 corresponds to the furthest position on the left and 10 to the furthest position on the right. Would you tell me the point on this scale at which you would place each of the following parties (BE, CDU, CDS/PP, PS and PSD) or what number on the scale you would give to each of them?' Table 4 below shows the voters' perceptions on parties' positions.

[Table 4. Mean perceptions of political parties' left-right positions - ABOUT HERE]

With the exception of the PS and - to a lesser degree - the CDS/PP, there is a substantial discrepancy between the positioning of parties as perceived by their MPs and by their electorate. For these two major parties, the perceptions of voters and MPs concerning the ideological location of the party almost coincide. This data reflects the differences between parties observed earlier.

Figures 1 and 2 provide a spatial representation of the congruence between the mean positions of the voters on the ideological spectrum (on the horizontal axis) and the 
positioning of the parties they voted for (on the vertical axis), with Figure 1 showing voters' perceptions and Figure 2 those of MPs.

[Figure 1. Congruence between voters' ideological self-placement and their perception of their political party's position - ABOUT HERE]

[Figure 2. Congruence between voters' ideological self-positioning and MPs' perception of their political party's position - ABOUT HERE]

In Figure 1, as we move from left to right, an almost perfect linear relationship is drawn between the point where the voters position themselves ideologically and the point where they place their parties. This relationship, however, is not perfectly diagonal, which would signify complete congruence with the parties. There is, rather, a slight bias at the extremes, with the voters for the parties furthest to the left placing themselves slightly to the right of their parties' positions. Also, the voters for the parties furthest to the right locate themselves to the left of their parties' positions. The PS emerges as the party that generates the greatest sense of ideological congruence among its own voters.

Figure 2 shows that the congruence between the electorate's and the parties' electoral positioning is not as large when the latter is inferred from the MPs' responses. Indeed, compared with the earlier figure, the relationship is less linear, reflecting the differences between the perceptions of voters and MPs regarding the parties. Still, it is possible to state that, with the exception of the PSD, the parties' positions are, generally speaking, correctly perceived by their electorates (Figure 1), though underestimated for the most polarised parties. Only the PSD electorate located their party significantly further to the right than it is in fact placed by its MPs.

It may be concluded from these findings that, despite voters' difficulties in objectively identifying their parties' ideological positions, they correctly perceive the discrepancy between their own and their party's positions on the left-right scale, i.e. whether the party is congruent, or more or less polarised than its electorate, a finding that has been confirmed at the European level (Van der Brug \& Van der Eijk 1999, pp. 144-146). Accordingly, although we have confirmed our hypothesis which stated that the electorate cannot objectively identify their political parties' ideological positions, what seems certain is that most electorates in our sample correctly perceive the 
discrepancy that exists between these positions, as well as their own more centrist ideological positions, when compared to the elites of the parties they support.

\section{Attitudes towards Democracy}

In modern democratic systems, a significant difference is normally acknowledged between elite political attitudes and those of the public, in particular concerning the understanding and meaning of democratic norms. Although the political elite are normally seen as favouring the centralisation of power, it is also recognised that elites share a broad consensus in defending democratic rules and procedures (Etzioni-Halevy 1993, p. 110). Further, it has been demonstrated that this commitment by the elite to democratic norms is stronger than that of the electorates (Putnam 1976, p. 116; Dye \& Zeigler 2006, p. 17). These findings support our second hypothesis, according to which we would expect that the parliamentary elite holds more favourable attitudes to democracy than the electorates.

To evaluate perceptions on democracy, we included three variables that measure the degree of agreement with the following statements: 'In a democracy, the economic system works badly', 'Democratic forms of government are highly indecisive and allow for too much quibbling', and 'Democratic forms of government are not good at maintaining order'. Preference for a democratic system was measured on the basis of the degree of agreement with the following expression: 'Democratic forms of government may have problems but they are better than any other system of government'.

A striking aspect of the results obtained concerns the degree of overt negative feelings about democratic government on the part of voters, as compared to MPs. In only one of the four variables considered do MPs appear relatively displeased with the way democracy operates. Namely, 29.3 per cent agree that 'democratic forms of government are indecisive and allow too much quibbling'. For every other variable, the total percentage of disagreement by MPs does not exceed 7 per cent. Only one MP out of a total of 79 surveyed thought there might be a political system that is better than democracy.

Concerning the voters, a substantially more pessimistic consensus can be observed: 66.5 per cent, 74.7 per cent and 49.9 per cent of respondents, respectively, agree that in a democracy the economy works badly, that the political system of 
democracy is indecisive, and that it is not good at maintaining order. Moreover, a significant percentage of the public (14 per cent) disagrees that democracy is the best political system.

The greater satisfaction of the political elite with democracy has been demonstrated elsewhere (Saglie \& Heidar 2004, p. 391). The magnitude of the values in our sample, however, raises doubts about the supposed support of the Portuguese for democracy, which has been optimistically asserted by other studies (e.g. Morlino \& Montero 1995; Schmitter 1999, p. 458). Table 5 confirms that, irrespective of the political party they represent, MPs have a more favourable position towards democracy and a clearer preference for a democratic system than their electorates. The differences between MPs and voters are particularly divergent in the cases of the communist CDU and the new left BE.

[Table 5. Mean attitudes towards democracy - ABOUT HERE]

Another interesting finding emerges from this table. Concerning the issue of attitudes towards democracy, voters' views are relatively similar to each other, regardless of party, as are MPs' views. Moreover, the similarity of position is greater among voters of different parties and among the group of MPs as a whole than among voters and MPs of the same party. This leads us to posit that it is essentially the condition of being an MP, in contrast to that of being a voter, that contributes to the difference of opinions, and not party affiliation. It could, however, also be argued that the lack of issue salience concerning attitudes towards democracy may have contributed to these results.

We turn now to the relationship between left-right self-placement and attitudes towards democracy. For voters, the relationship is not statistically significant. However, with respect to MPs, those who place themselves on the left of the ideological spectrum display rather more positive attitudes towards democracy than their fellow members of parliament. This relationship is statistically significant $(\mathrm{p}<0.05)$, albeit only weakly so (0.23 correlation coefficient). Despite this, the increase in positive attitudes towards democracy on the left is not accompanied by an increase in negative attitudes on the right. Therefore, this statistically significant relationship only signals a higher degree of support for democracy among left MPs. 


\section{Conclusion}

From the outset, we were clear that the degree of congruence between the political elite and the voters cannot be directly understood as a proxy for enhanced democratic political representation. Still, the empirical evidence analysed in this study allows us to formulate a set of conclusions with explicit implications for democratic representation.

Firstly, there is a great deal of variance concerning congruence on the left of the political spectrum. Indeed, left-wing parties register both the greatest and least ideological representation. The socialist PS is the party which repeatedly emerges with the greatest congruence in positions on the left-right scale, not only measured in objective terms but also with regard to the electorate's perception of the party's location. On the contrary, and against both our expectations and the existing literature, the communist party exhibits the least ideological congruence among Portuguese parties.

In this scenario, the relative centrism of the electorate seems to be an important element of the story, which affects all parties. It shows that the electorate has a rather narrower ideological spectrum when compared with the parliamentary elite. This is not unique to Portugal. It has already been noted in previous research on Sweden (Esaiasson \& Holmberg 1996, pp.176-177, p. 312) and the European Parliament (Thomassen \& Schmitt 1999, pp. 191-195). To a large extent, this divergence might be explained by the lower level of political sophistication among the public.

Yet, more than the ideologically centrist position of the electorate, it is interesting to stress that voters perceive their relative position regarding their representatives correctly. It is the MPs of the five Portuguese parties who wrongly assume full congruence with their electorates. The voters, however, are able to recognise that a discrepancy exists. Moreover, in almost all parties, the voters are able to identify accurately the ideological direction in which this discrepancy occurs. This means that, contrary to what could be expected, voters are more able than the elite to perceive ideological distances between voters and parties.

The generality of the findings on ideological representation, far from placing Portugal in an unusual or idiosyncratic position in the European context, show that it fits the European matrix of ideological representation. The same can be said with respect to Spain and Italy, the only two south European countries for which similar data was available. 
In democratic societies, matters connected with democratic values foster consensus and provoke little party political division. For this reason, the congruence among voters and MPs is higher in the case of attitudes towards democracy than with regard to ideology, which, by its very nature, generates political dissension. ${ }^{11}$ There is also a higher degree of homogeneity within the general public than among MPs as a whole. According to May, there are transversal similarities among party leaders because their circumstances and status cut across party lines, and their ability 'to imbibe the spirit of the parliamentary house, to think of [themselves] as national legislator[s] first and partisan[s] second' (May 1973, p. 151). Irrespective of party, the representatives and the represented display different conceptions of democracy, with the former viewing it more favourably.

In democratic systems, some degree of divergence on the positions of MPs and voters should be not only plausible but expected. Democracy should not necessarily be considered stronger as a consequence of higher levels of congruence. In fact, as noted by Przeworski et al. (1999), incongruent democratic governments (vis-à-vis their supporters) are conceivable. Inversely, it is possible to find congruent non-democratic governments too. However, it is supposed that democratic governments and democratic political parties produce reasonable levels of similarity and correspondence of positions with their supporters. Our findings suggest that, with the two exceptions of the extreme left and the global divergences in attitudes towards democracy, the congruence produced by the Portuguese political parties is reasonable and median in the European context. In other words, notwithstanding the feelings of distrust, distance and dissatisfaction of the Portuguese voters towards their representatives noted by Magalhães (2004), this does not appear to lead to a different pattern of representation in the European context.

Low party levels of congruence, however, also perceived by the electorate, could potentially generate a further distancing of voters from parties. As a consequence, parties could be further weakened. Given the fact that the electorate's perceptions can be particularly accurate, this is an important matter for parties to consider.

Finally, it is important to note the methodological limitations of our study. These relate to the dimension of the samples used, which are relatively small for some of the parties considered. Although such limitations are quite common in research of this kind, they suggest caution in interpreting the results. Further research on this subject should allow us to overcome these constraints. 


\section{References}

Achen, C.H. (1978) 'Measuring representation', American Journal of Political Science, vol. 22, no. 3, pp. 475-510.

Barnes, S.H. (1977) Representation in Italy. Institutionalised Tradition and Electoral Choice, The University of Chicago Press, Chicago and London.

Belchior, A.M. (2007) Democracia e Representação Partidária: a Elite Parlamentar e os Cidadãos Eleitores, PhD Thesis, Instituto de Estudos Políticos,Universidade Católica Portuguesa, Lisboa.

Birch, A.H. (1971) Representation, Pall Mall Press, London.

Budge, I. (2000) 'Expert judgements of party policy positions: uses and limitations in political research. Research note', European Journal of Political Research, vol. 37, no. 1, pp. 103-113.

CIES-ISCTE (2006) Participation and Democratic Deliberation Project, Lisboa, ISCTE.

CIES-ISCTE (2007) A Study of Portuguese MPs. Lisboa, ISCTE.

Clausen, A.R., Holmberg, S. \& de Haven-Smith, L. (1983) 'Contextual factors in the accuracy of leader perceptions of constituency views', The Journal of Politics, vol. 45 , no. 2 , pp. $449-472$.

Converse, P. \& Pierce, R. (1986) Political Representation in France, The Belknap Press of Harvard University Press, Cambridge and London.

Dalton, R. (1985) 'Political parties and political representation. Party supporters and party elites in nine nations', Comparative Political Studies, vol. 18, no. 3, pp. 267-299.

Dye, T. R. \& Zeigler, H. (2006) The Irony of Democracy, 13th edn, Thomson Wadsworth, Belmont.

Esaiasson, P. \& Holmberg, S. (1996) Representation from Above. Members of Parliament and Representative Democracy in Sweden, Dartmouth, Aldershot.

Etzioni-Halevy, E. (1993) The Elite Connection. Problems and Potential of Western Democracy, Polity Press, Cambridge.

Eulau, H. (1987) 'The congruence model revisited', Legislative Studies Quarterly, vol. 12, no. 2, pp. 171-214. 
Eulau, H. \& Karps, P. (1977) 'The puzzle of representation: specifying components of responsiveness', Legislative Studies Quarterly, vol. 2, no. 2, pp. 233-254.

Gunther, R. (2007) 'Portuguese elections in comparative perspective: parties and electoral behaviour in Southern Europe', in Portugal at the Polls, eds A. Freire, M. Costa Lobo \& P. Magalhães, Lexington Books, Lanham, pp. 11-47.

Holmberg, S. (1999) 'Wishful thinking among European parliamentarians', in Political Representation and Legitimacy in the European Union, eds H. Schmitt \& J. Thomassen, Oxford University Press, Oxford and New York, pp. 235-251.

Huber, J.D. \& Powell, G.B. Jr. (1994) 'Congruence between citizens and policy makers in two visions of liberal democracy', World Politics, vol. 46, no. 3, pp.291-326.

Jacobs, L.R \& Shapiro, R.Y. (2000) Politicians don't Pander. Political Manipulation and the Loss of Democratic Responsiveness, University of Chicago Press, Chicago.

Jewell, M.E. (1983) 'Legislator-constituency relations and the representative process', Legislative Studies Quarterly, vol. 8, no. 3, pp. 303-337.

Klingemann, H.-D. (1995) 'Party positions and voter orientations', in Citizens and the State, eds H.-D. Klingemann \& D. Fuchs, Oxford University Press, New York, pp. 183-205.

Lopes, F.F. (2004) Os Partidos Políticos. Modelos e Realidades na Europa Ocidental e em Portugal, Celta Editora, Oeiras.

Madison, J. (2001) 'The same subject continued, the utility of the union as a safeguard against domestic faction and insurrection', in The Federalist, Paper no.10, eds A. Hamilton, J. Lay \& J. Madison, Liberty Fund, Indianapolis, pp. 42-49, (original edition 1787).

Magalhães, P. (2004) 'Democratas, descontentes e desafectos: as atitudes dos portugueses em relação ao sistema político', in Portugal a Votos. As Eleições Legislativas de 2002, eds A. Freire, M. Costa Lobo \& P. Magalhães, Instituto de Ciências Sociais, Lisboa, pp. 333-361.

Manin, B. (1995) Principes du Gouvernement Représentatif, Éditions Calmann-Lévy, Mesnil-sur-1'Estrée.

May, J.D. (1973) 'Opinion structure of political parties: the special law of curvilinear disparity', Political Studies, vol. 21, no. 2, pp. 135-151. 
McClosky, H., Hoffmann, P.J. \& O'Hara, R. (1960) 'Issue conflict and consensus among party leaders and followers', American Political Science Review, vol. 54, no. 2 , pp. 406-427.

Miller, W. \& Stokes, D. (1963) 'Constituency influence in Congress', American Political Science Review, vol. 57, no. 1, pp. 45-56.

Miller, W., Pierce, R., Thomassen, J., Herrera, R., Holmberg, S., Esaiasson, P. \& Wessels, B. (1999) Policy Representation in Western Democracies, Oxford University Press, Oxford and New York.

Morlino, L. \& Montero, J.R. (1995). 'Legitimacy and democracy in Southern Europe', in The Politics of Democratic Consolidation. Southern Europe in Comparative Perspective, eds R. Gunther, P.N. Diamandouros \& H.-J. Puhle, The John Hopkins University Press, Baltimore and London, pp. 231-260.

Opello, W.C. Jr (1988) 'O Parlamento português: análise organizacional da actividade legislativa', Análise Social, no. 100, pp.127-150.

Panebianco, A. (1990) Modelos de Partido, Alianza, Madrid.

Pierce, R. (1999) 'Mass-elite issue linkages and the responsible party model representation', in Policy Representation in Western Democracies, eds W. Miller, R. Pierce, J. Thomassen, R. Herrera, S. Holmberg, P. Esaiasson \& B. Wessels, Oxford University Press, Oxford and New York, pp.9-32.

Pitkin, H.F. (1967) The Concept of Representation, University of California Press, Berkeley, Los Angeles and London.

Porras Nadales, A.J. (1996) El Debate sobre la Crisis de la Representación Política, Editorial Tecnos, Madrid.

Powell, G. B. Jr. (2000) Elections as Instruments of Democracy, Yale University Press, New Haven and London.

Przeworski, A., Stokes, S. \& Manin, B. (1999) Democracy, Accountability, and Representation, Cambridge University Press, Cambridge.

Putnam, R. (1976) The Comparative Study of Political Elites, Prentice-Hall, New Jersey.

Saglie, J. \& Heidar, K. (2004) 'Democracy within Norwegian political parties. Complacency or pressure for change?', Party Politics, vol. 10, no. 4, pp. 385405. 
Schmitt, H. \& Thomassen, J. (1999) 'Distinctiveness and cohesion of parties', in Political Representation and Legitimacy in the European Union, eds H. Schmitt \& J. Thomassen, Oxford University Press, Oxford and New York, pp. 111-128.

Schmitter, P. (1999) Portugal: do Autoritarismo à Democracia, Instituto de Ciências Sociais, Lisboa.

Thomassen, J. (1994) 'Empirical research into political representation: failing democracy or failing models?', in Elections at Home and Abroad, eds M.K. Jennings \& T.E. Mann, The University of Michigan Press, Ann Arbor, pp. 237264.

Thomassen, J. (1999) 'Political communication between political elites and mass publics', in Policy Representation in Western Democracies, eds W. Miller, R. Pierce, J. Thomassen, R. Herrera, S. Holmberg, P. Esaiasson \& B. Wessels, Oxford University Press, Oxford and New York, pp. 33-58.

Thomassen, J. \& Schmitt, H. (1999) 'Issue congruence', in Political Representation and Legitimacy in the European Union, eds H. Schmitt \& J. Thomassen, Oxford University Press, Oxford and New York, pp. 186-208.

Van Der Brug, W. \& Van Der Eijk, C. (1999) 'The cognitive basis of voting', in Political Representation and Legitimacy in the European Union, eds H. Schmitt \& J. Thomassen, Oxford University Press, Oxford and New York, pp. 129-160.

\section{Acknowledgements}

The author wishes to thank José M. Leite Viegas, André Freire and Helena Carreiras for their insightful suggestions and comments on previous versions of this article. Special thanks are due to José M. Leite Viegas for his invitation to join the project Participation and Democratic Deliberation.

\section{Notes}

For detailed information about the Portuguese party system, see for instance Lopes (2004) and Gunther (2007). 
2 Other studies approached this subject with a higher degree of complexity, namely by allowing for influence by different intra-party echelons of leadership on levels of congruence (May 1973).

3 Other works could be added to this list. However, either because they are theoretical or simple methodological replications of one of the studies mentioned above, we do not include them here.

4 As in the case of other authors (e.g. Huber \& Powell 1994), the median is used instead of the mean in order to overcome the bias that the latter may introduce in variables which do not have a normal distribution.

5 In contrast to other electoral systems to which this measure has been applied, in the Portuguese case it is only possible to establish five types of dyadic correspondence. It is not possible to establish correspondences at the level of electoral constituencies because voters do not vote directly for candidate MPs, but for parties. Therefore, correspondences are only established at the level of each of the five Portuguese parties. The regression and correlation coefficients are, therefore, calculated for the mean positions of the elected and electorate of these five parties. Despite their statistical drawbacks, we opted for these measurements for the following reasons. Firstly, we are interested in replicating in the analysis for Portugal the different aspects of measuring representation through congruence. Secondly, we have inserted some safeguards, namely through the additional action of applying other statistical measures. Thirdly, the additional information obtained from the regression and correlation coefficients, though it necessarily requires care in interpretation, may become important when read together with the other measures. Despite the statistical limitations, from the analytical viewpoint the measures described above enable confirmation of the direction and intensity of the relationship between the elite and the voters shown by other measures.

6 On the statistical grounds for this measure, see especially Pierce (1999, pp. 16-17).

7 Higher Institute of Social Sciences and Business Studies, University of Lisbon.

8 The voters' survey comprised a sample of 1,001 eligible voters (18-70 years old). Proportional quota sampling and face to face interviews were used. The survey of parliamentarians used face to face interviews. The response rate of 79 out of $230 \mathrm{MPs}$ corresponded to $34.3 \%$ of the universe. The number of respondents from each party were as follows: 38 from PS (out of the total of 121 party MPs), 28 from PSD (out of 75 MPs), seven (out of 12) from CDS/PP, two (out of 12) from CDU, four (out of 14) from 
$\mathrm{BE}$ and two (out of two) for PEV. Some methodological problems arise from the comparison between voters and MPs. These problems have been widely reported in the literature on this subject (e.g. Eulau 1987, pp. 171-172; Pierce 1999, pp. 13-15), two of the most important being the conceptual differences between voters' and MPs' political and ideological positions, and, as a consequence, the higher dispersion of voters' positions comparative to those of MPs.

9 It should be noted that, although the PS displays the least difference in the means, it presents the greatest standard deviation for the MPs, followed by the PSD. This is understandable on account of the more centrist positioning of these two parties. The tendency towards less internal cohesion in the larger parties at the centre in comparison to the smaller and more extreme parties has already been demonstrated at a European level (Schmitt \& Thomassen 1999, pp. 124-125). This lower degree of internal homogeneity in the elite, however, affects the extent of the congruence encountered for the PS.

10 As we have no data available to measure the political parties' actual policies and ideological positions, and given the sense of near-convergence of position between how MPs define their own positions and how they place their parties, we used the positions of the former to measure those of the latter. The authoritative nature of party elites' positions in defining those of their parties (Budge 2000) and in the case of Portugal, MPs' relative lack of independence in relation to the political parties (see e.g. Opello 1988, pp. 134-143), supports this option. However, this is not an optimal but only an analytical solution: MPs' political positions are not necessarily identical with the party line.

11 Greater congruence in non-structural rather than structural matters has been registered in other European countries (Thomassen 1999, pp. 46-51). 